\title{
Reservoir longitudinal gradient promotes ordered losses on diversity and density of Ephemeroptera community
}

\author{
S. M. Melo ${ }^{a}$, G. D. Pinha ${ }^{b *}$, F. H. Ragonha ${ }^{b}$, H. M. Fontes-Junior ${ }^{c}$ and A. M. Takeda

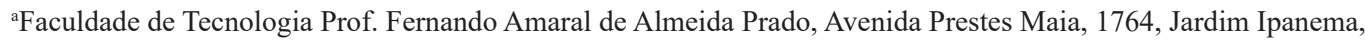 \\ CEP 16052-045, Araçatuba, SP, Brazil \\ 'Programa de Pós-graduação em Ecologia de Ambientes Aquáticos Continentais, Universidade Estadual de Maringá - \\ UEM, Avenida Colombo, 5790, CEP 87020-900, Maringá, PR, Brazil \\ 'Divisão de Reservatório - MARR.CD, Usina Hidrelétrica de Itaipu, Avenida Tancredo Neves, 6731, CEP 85856-970, \\ Foz do Iguaçu, PR, Brazil \\ *e-mail: pinha.gd@gmail.com
}

Received: June 17, 2017 - Accepted: July 19, 2017 - Distributed: November 30, 2018

(With 6 figures)

\begin{abstract}
Reservoir operations alter, eliminate or restrain the natural hydrologic cycles. Biotic community has become subject to these non-cyclic events, responding by reducing the species diversity. Ephemeroptera species present distinct responses to environmental deterioration such that poses this assemblage between the most useful groups in biomonitoring programs. We hypothesized an alteration in beta diversity at the longitudinal species gradient, which will be influenced mainly by species losses between zones. Changes in temporal beta diversity is also expected, but the main drivers of such alterations will be the species turnover between the sampling period. Ephemeroptera community was monitored in nine sampling points from Itaipu Reservoir, where were installed three sets of substrates composed by a float and 2 wooden substrates. We took biological samples in triplicates monthly, from June-01 to August-02. Our initial hypothesis was partially supported and with significant variations only for spatial approach, between the Reservoir zones. The generated ordering from Non-Metric Dimensional Scale - NMDS - corroborated with spatial analyzes, with the formation of two groups along the gradient zonation of the reservoir. The temporal ordination showed no clear pattern. As expected, the contribution to beta diversity was different for our two approaches, such that the loss of species was more important along the spatial gradient and despite of no significant result, the species replacement was more important among months. The spatial results lead us to infer that differences in limnological characteristics between zones are important for determining differences in Ephemeroptera composition and can reflect the dependency degree of the species in relation to the lentic and sometimes-lotic conditions, mainly in the riverine zone of reservoirs. On the other hand, the absence of a temporal pattern can be result of chaotic variations in the physical and chemical attributes imposed by the reservoir operation, disrupting continuity of the biota and natural succession processes.
\end{abstract}

Keywords: beta diversity, spatial distribution, temporal variation, richness.

\section{O gradiente longitudinal de um reservatório promove perdas ordenadas na diversidade e densidade da comunidade de Ephemeroptera}

\section{Resumo}

As operações de reservatórios alteram, eliminam ou restringem os ciclos hidrológicos naturais. A comunidade biótica torna-se sujeita a estes eventos não-cíclicos, respondendo com a redução da diversidade de espécies. As espécies de Ephemeroptera apresentam respostas distintas à deterioração ambiental, sendo o grupo muitousado em programas de biomonitoramento. Nós hipotetizamos uma alteração na diversidade beta das espécies no gradiente longitudinal, influenciada principalmente pelo componente aninhamento com a consequente perda de espécies entre as zonas do reservatório. Também são esperadas mudanças na diversidade beta entre os meses de amostragem, mas o principal fator dessas alterações será a substituição das espécies entre os períodos, em função dos rápidos ciclos de vida que o grupo apresenta. A comunidade Ephemeroptera foi monitorada em nove pontos amostrais do reservatório de Itaipu, onde foram instalados três conjuntos de substratos compostos por um flutuador e 2 substratos de madeira. Tomamos amostras biológicas em triplicatas mensalmente, de junho de 2001 a agosto de 2002. Nossa hipótese inicial foi parcialmente suportada, com variações significativas apenas na escala espacial. A ordenação gerada pelo Escalonamento Dimensional Não-Métrico - NMDS - corroborou com as análises espaciais, com a formação de dois grupos ao longo do gradiente de zonação do reservatório. A ordenação temporal não mostrou um padrão claro. Como esperado, a contribuição para 
a diversidade beta foi diferente para nossas duas abordagens, de modo que a perda de espécies foi mais importante ao longo do gradiente espacial e apesar de não haver resultado significativo, a substituição das espécies foi mais importante entre os meses de amostragem. Os resultados espaciais levam-nos a inferir que as diferenças nas características limnológicas entre as zonas são importantes para determinar as diferenças na composição de Ephemeroptera e podem refletir o grau de dependência das espécies em relação às condições lênticas e às vezes lóticas, principalmente na zona fluvial dos reservatórios. Por outro lado, a ausência de um padrão temporal pode ser resultado de variações caóticas nos atributos físicos e químicos impostos pela operação do reservatório, que interrompem a continuidade da biota e os processos de sucessão naturais.

Palavras-chave: diversidade beta, distribuição espacial, variação temporal, riqueza.

\section{Introduction}

Reservoirs are complex systems exhibiting a range of ecological, economic and social interactions (Tundisi, 1996). A major impact of reservoirs is the reduction of natural cyclicity of riverine environment. Reservoir operations alters, eliminate or restrain the natural hydrologic cycles. Biotic community become subject to these non-cyclic perturbations related to operation of dams, exacerbating the instability induced by these new environments and responds by reducing the species diversity, which leading to simpler assemblies (Agostinho et al., 1999).

In ecological terms, due to human interference, reservoir systems show combinations of riverine and lacustrine elements. A characteristic of these systems is the presence of a longitudinal gradient with three distinct zones, named by Thornton et al. (1981) as riverine, transition and lacustrine zones. Each zone presents differences in physical and chemical characteristics which lead to differences in biotic assemblages (Velho et al., 2001; Moreno-Ostos et al., 2008). In this sense, a fundamental concept regarding the structure of biological communities and its variation is beta diversity, which can be defined as the variation in community composition between sites or periods (Tuomisto, 2010; Melo et al., 2011). Besides the importance of beta diversity to explain differences between two biological communities, Simpson (1943) suggested the existence of other features leading to dissimilarity in species communities between sites which were not related to turnover. To evaluate the factors changing beta diversity, Baselga (2012) created a new index where the beta diversity can be partitioned in nestedness and turnover.

Species nestedness, in the beta diversity partitioning concept, is related to events where there are ordered species losses among both spatial and temporal scales (Baselga, 2012). On the other hand, the turnover component determine the exchange of some species by others, as a consequence of environmental conditions, or any spatial or temporal restrictions (Qian et al., 2005). The partitioning of the beta diversity in these components, in addition to the relative importance of environmental and spatial factors, can be important tools for a better understanding of the spatial and temporal dynamics in biological communities (Baselga, 2012).Currently, the dissimilarity index as the Jaccard or Sørensen have been widely used to evaluate the beta diversity and its components for several groups of organisms, including invertebrates (Baselga, 2010; Fattorini and Baselga, 2012), terrestrial vertebrates (Dobrovolski et al., 2012; Tonial et al., 2012) and aquatic vertebrates (Florentino and Penha, 2011). Ephemeroptera is an important component in most freshwater systems, being found in various types of habitats (Dominguez et al., 2001; Barber-James et al., 2008). According to Merritt and Cummins (1996) and Silva (1997) Ephemeroptera is highly sensitive to ecological disturbances. Ephemeroptera species present distinct responses to environmental deterioration so that poses them between the most useful groups in biomonitoring programs (Domínguez et al., 2006; Salles et al., 2004). The distribution of species can be also related to season (Nolte et al., 1996; Melo et al., 2002), water level (Melo et al., 1993, 2004; Tabacchi et al., 1993) and substratum (Giller and Cambell, 1989; Francischetti et al., 2004; Goulart and Callisto, 2005; Shimano et al., 2011).

The responses of aquatic fauna to hydrological modifications induced by dams are still not well understood within the Neotropical fauna (Nelson, 1994). In function to great deeps of reservoirs, artificial substrates can reveal alterations in the composition and abundance of the Ephemeroptera species along spatial and temporal gradients. While spatial differences in Ephemeroptera community would evidence changes in habitat structure between reservoir zones, temporal differences would allow evaluating the stability of environmental conditions and the adaptation capacity of species in reservoirs. Based on above discussion, we hypothesized differences in beta diversity which is influenced both spatially and temporally so that (i) spatial beta diversity of Ephemeroptera community is driven mainly by nestedness of species along the longitudinal gradient between reservoir zones while (ii) temporal beta diversity is driven by turnover between the sampling period.

\section{Methods}

\subsection{Area of the study}

Itaipu reservoir is located at the Paraná River ( $24^{\circ} 05^{\prime}$ to $25^{\circ} 33^{\prime} \mathrm{S}, 5^{\circ} 00^{\prime}$ to $54^{\circ} 37^{\prime} \mathrm{W}$ ), border between Brazil and Paraguay. Its length reaches $170 \mathrm{~km}$, with a surface area of $1,350 \mathrm{~km}^{2}$ and a basin area of approximately $820,000 \mathrm{~km}^{2}$. The residence time of water is approximately 40 days, and only 29 days in the main 
channel. The average depth is $22 \mathrm{~m}$ and the maximum $170 \mathrm{~m}$ in stretches nearer the dam.

Pagioro and Thomaz (2002) defined three different zones of Itaipu Reservoir based on the limnological characteristics: riverine, transition and lacustrine zones where the extension of each zone is approximately 25,35 and $90 \mathrm{~km}$, respectively (Okada et al., 2005). The samples were taken at nine sampling point along the longitudinal gradient of the reservoir where were installed three sets of substrates composed by a float and 2 wooden substrates. Guaíra and Oliveira Castro were located in the riverine zone and then named Riverine 1 and Riverine 2 respectively; Porto Mendes and Porto Britânia represented the transition zone and named Transition 1 and Transition 2 respectively. The sites: Entre Rios, Santa Helena, São Miguel do Iguaçu, Santa Terezinha de Itaipu and ICLI represented the lacustrine zone and then, named Lacustrine1, Lacustrine2, Lacustrine3, Lacustrine4 and Lacustrine5, respectively (Figure 1).

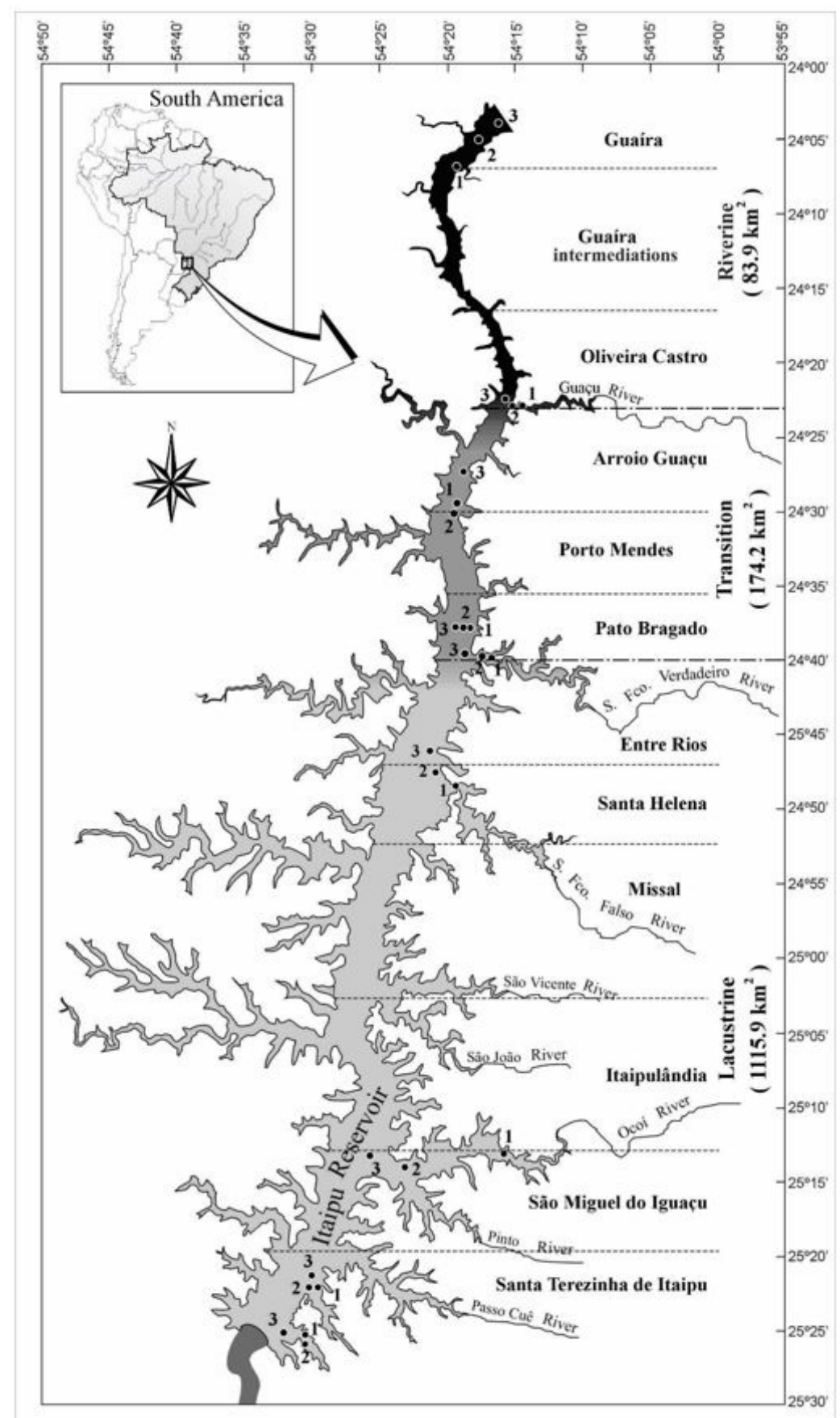

Figure 1. Location of the sampling stations from longitudinal gradient of Itaipu Reservoir. 


\subsection{Biological sampling}

For the study on the Ephemeroptera in the longitudinal gradient, at each site we sampled three sets of artificial substrates monthly, from June 2001 to August 2002. The samples of material adhered to each substratum were sampled with a square tray of $8 \mathrm{~cm} \times 8 \mathrm{~cm}\left(0.0064 \mathrm{~m}^{2}\right)$, and fixed in polyethylene bottles containing $70 \%$ alcohol. For the analysis, we considered each set of substrates of each site as a sample unity.

Ephemeroptera nymphs were separated, counted and subsequently identified in the laboratory under the stereoscopic and optical microscope. The immature stages were identified to the minimum possible taxonomic level, in accordance with Lugo-Ortiz and McCafferty (1996), Domínguez et al. (2001), Molineri (2001), Salles et al. (2004), Dias (2005), Dias and Salles (2005), Domínguez et al. (2006).

\subsection{Statistical analyzes}

In order to describe variations in Ephemeroptera communities structure between the different zones and months, the following attributes were used: i) Density (Ind. $\mathrm{m}^{-2}$ ), calculated per square meter, using the area removed from substrates $\left(0.0064 \mathrm{~m}^{2}\right)$; and ii) Taxonomic richness (S) - number of registered taxa. The differences between the values of attributes were tested by analyses of variance (one-way ANOVA) considering the significance of $\mathrm{p}<0.05$.

A non-metric multidimensional scaling (NMDS) was performed with the abundance of Ephemeroptera taxa between the zones from Itaipu Reservoir, considering the longitudinal gradient (riverine, transition and lacustrine)) and between collection periods. NMDS was chosen because it is one of the most robust ordination analyses to nonlinear situations (Clarke, 1993). The distances were calculated through the Bray-Curtis similarity index. The resolution distortion in two dimensions is expressed by the value of stress. The closer to zero the stress is, better will be the fit between original distance of objects and arrangement obtained by the analysis (Legendre and Legendre, 1998). The Lacustrine3 were excluded of the analysis because no individual was found during the experiment. Analysis of variance for multivariate permutation (PERMANOVA) was used to assess the significance of ordination of Ephemeroptera composition $(\alpha=0.05)$.

Beta diversity provided dissimilarity measures between different sites and periods. To evaluate the causes behind the results, we partitioned the overall dissimilarity for multiple sites (Jaccard dissimilarity) into the following fractions according to Baselga (2012): dissimilarity due to species replacement (turnover) and dissimilarity due to nestedness (nestedness-resultant fraction of beta diversity). Thus, we evaluated whether the total dissimilarity found was related to the loss (nestedness component) or replacement (turnover component) of species between months. Finally, for better visualization of beta diversity patterns, we built incidence matrices for both spatial and temporal approaches.

These calculations were performed during routine work executed in the vegan (for NMDS ordination, PERMANOVA tests and temperature matrix) and betapart (for beta diversity analysis) packages of R (R Development Core Team, 2014). The figures were built in Statistica 7.1 program (Statsoft Inc, 2005).

\section{Results}

Significant differences were found only between reservoir zones (Figure 2A), where the highest values of density and taxa richness of Ephemeroptera were observed for riverine and transitional zones. Although there has been an intense fluctuation in these attributes throughout the collection period, they were not significant (Figure 2B).

NMDS ordination corroborated with the previous spatial analyzes, clustering the data into two groups along the reservoir-zones gradient (Figure 3A). Riverine and transitional zones were more related to each other than with the sites of lacustrine zone. By the permutation test performed the ordination was significant ( $F$ model $=6.932, p=0.001$; Table 1$)$, and showed a pattern of spatial variation between reservoir zones. However, the temporal ordination, by sampling periods, showed no clear pattern (Figure 3B), and the permutation test was no significance $(\mathrm{F}$ model $=1.12, \mathrm{p}=0.37)$.
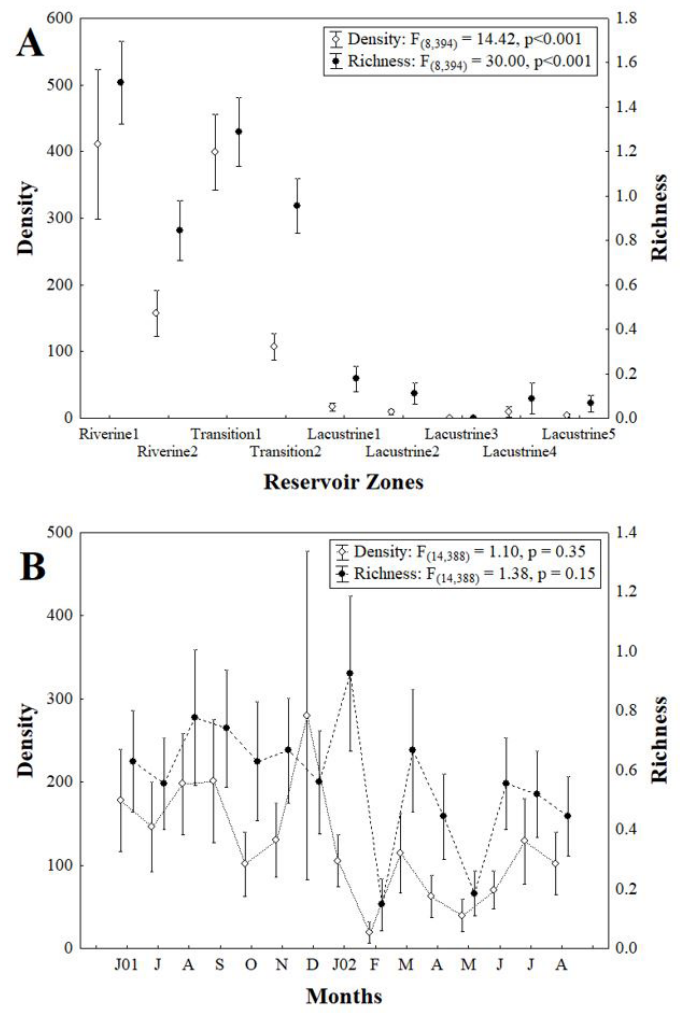

Figure 2. Mean and standard error for Density and Richness of Ephemeroptera taxa between (A) the zones (spatial) and (B) months (temporal) from longitudinal gradient of Itaipu Reservoir. 
The main contribution for the analysis of beta diversity partitioning at spatial scale was by the nestedness-resultant fraction of beta diversity (Table 2), showing losses of species and reduction of abundance between the zones as the main ecological alterations of Ephemeroptera community at the longitudinal gradient (Figure 4A).

For temporal scale, the turnover fraction was the principal driver for the beta diversity of Ephemeroptera composition between months, however, no significant result was observed for the months sampled (Figure 4B).
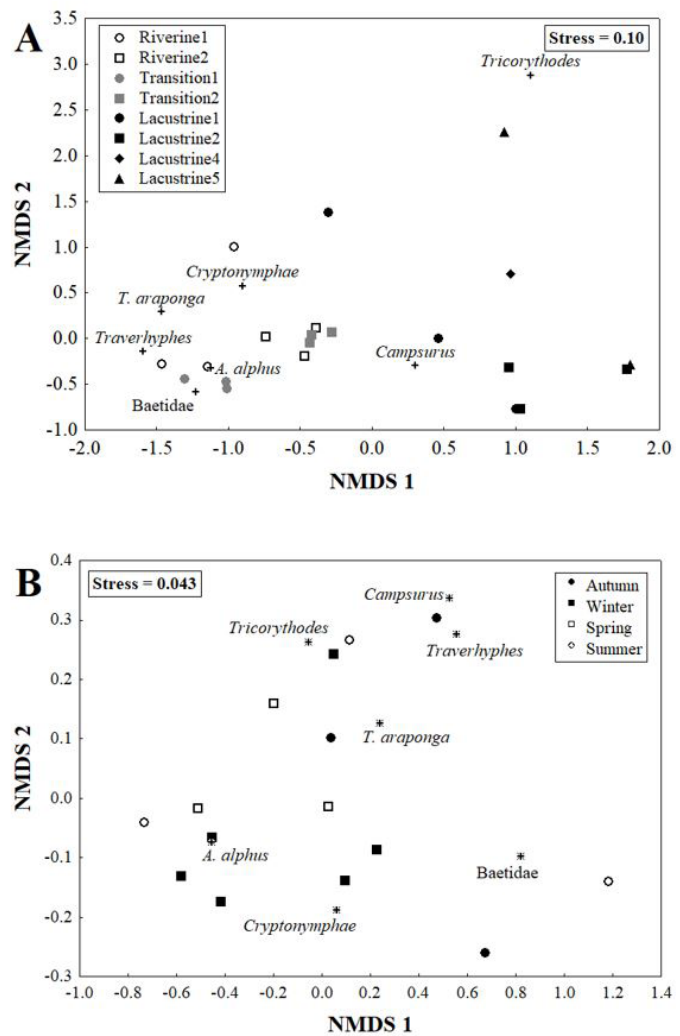

Figure 3. NMDS ordination for Ephemeroptera taxa between (A) the zones (spatial) and (B) months (temporal) from longitudinal gradient of Itaipu Reservoir. $T$. araponga = Tricorytopsis araponga; A. alphus $=$ Americabaetis alphus.

\section{Discussion}

Our initial hypothesis was partially supported and only a spatial variation was significant. Ephemeroptera community was strongly structured in the spatial approach, both in density and in richness, with significant differences between zones along the gradient of Itaipu Reservoir, but no significant temporal change was observed. Similar patterns were found by Terra et al. (2010), who reported reductions in the richness of fish community and no seasonal pattern in the longitudinal gradient of a Neotropical reservoir.

Spatial results from NMDS ordination lead us to infer that the limnological characteristics differentiated between zones are important for the determination of different Ephemeroptera composition. The riverine zone of Itaipu Reservoir presents characteristics of a lotic environment, with a brief water residence time, high levels of nutrient availability and higher stream flow velocity (Okada et al.,

Table 1. Results of PERMANOVA test for the NMDS ordination.

\begin{tabular}{lccc}
\hline \multicolumn{4}{c}{ PERMANOVA results } \\
\hline & Df & $\begin{array}{c}\text { F of } \\
\text { Model }\end{array}$ & $\boldsymbol{P}$ \\
\hline Reservoir zones & 2 & 6.932 & $0.001^{*}$ \\
Residuals & 19 & 0.578 & \\
Sampled periods & 3 & 1.1166 & 0.375 \\
Residuals & 11 & 0.76656 & \\
\hline
\end{tabular}

*significant value for $\alpha=0.05$. Df $=$ degrees of freedom; $\mathrm{F}$ of Model $=$ permuted values generated by PERMANOVA; $P=$ probability).

Table 2. Beta diversity partitioning of the abundance of Ephemeroptera taxa between zones (spatial) and periods (temporal) of Itaipu Reservoir.

\begin{tabular}{lc}
\hline \multicolumn{2}{c}{ Spatial beta diversity by Jaccard dissimilarity } \\
\hline Turnover fraction & 0.00 \\
Nestedness-resultant fraction & 0.44 \\
Overall Beta diversity & 0.44 \\
\hline \multicolumn{2}{c}{ Temporal beta diversity by Jaccard dissimilarity } \\
\hline Turnover fraction & 0.65 \\
Nestedness-resultant fraction & 0.15 \\
Overall Beta diversity & 0.80 \\
\hline
\end{tabular}
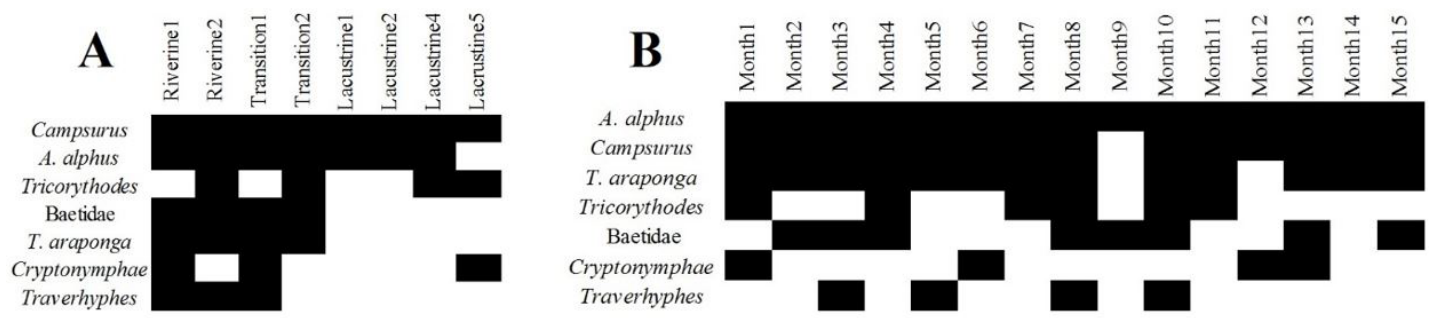

Figure 4. Matrix for presence (black squares) or absence (white squares) of Ephemeroptera taxa between (A) the zones (spatial) and (B) months (temporal) from longitudinal gradient of Itaipu Reservoir. 
2005). These factors certainly contributed to the greater density of nymphs, especially of Americabaetis alphus. The direct influence of the water inflow of the Paraná River to the reservoir riverine zone can have contributed to the distribution and colonization of the nymphs coming from upstream of the Paraná River.

Preferences of Ephemeroptera species for riverine systems were extensive studied in the past. For example, in the review of Brittain and Saltveit (1989) about effects of impoundment on mayfly community, the distribution of species was summarized according to environmental conditions. The authors related the mayfly distribution with their preferences for living in flow and shallow systems, and suggested a change in the mayfly fauna by river regulation. Similarly, Zelinka (1984) related a strong decrease in flow in an experimental stream with a considerable decrease in densities of mayfly nymphs. Changes in water temperature in dammed systems were also related to reductions in mayfly densities (Brittain and Saltveit, 1989) and could explain the variations found in species richness among the reservoir zones studied here.

Variations in beta diversity were different between our two approaches, being significant only amongreservoir zones. According to Baselga (2012), beta diversity partitioning reflects changes in community composition between sites or periods. The partitioning in the two components (turnover or nestedness fraction) is crucial for understanding the historic and present-day determinants of beta diversity (e.g. Dobrovolski et al., 2012; Hortal et al., 2011; Leprieur et al., 2011; Svenning et al., 2011). The ordered loss of species was more important along the spatial gradient. Great reduction of Ephemeroptera richness promoted by the species loss along reservoir zones, corroborating with Wetzel (1990) postulates. Despite no significative result, species replacement was more temporally than spatiallyHigher turnover contribution to beta diversity between months would imply in replacement of some species by others, because of environmental sorting or spatial and historical constraints (Qian et al., 2005).

Changes in limnological features among reservoir zones contributed to Ephemeroptera taxa decreasing from riverine to lacustrine zone, due to the restrictive characteristics of such zone. Differences in water velocity can explain the reduction in the density and richness of Ephemeroptera taxa. Hynes (1970) stated the water velocity as of vital importance, since many aquatic invertebrates are dependent of water for food and respiration. According to Oliveira et al. (2005), the lacustrine zone presents a low availability of nutrients and a long water residence period with reduction in the water velocity.

According to Wetzel (1990), perturbations imposed by reservoir operation is a chaotic succession of reactions marked by a reduction in the interdependence among species and a lower biotic stability, disrupting the continuity of biota and natural succession processes and can be related with our spatial results. On the other hand, Taniwaki et al. (2013) postulated the absence of marked seasonality for the most of nutrient concentrations in Brazilian reservoirs, so that the structure and composition of biological communities would reflect these environmental characteristics. Absence of temporal changes in limnological features of reservoir could lead to a more stable environment and then, resulting in absences of significant temporal variations of Ephemeroptera community. In a scenario of low species diversity, such result has a great concern in relation to species diversity in reservoirs because lower turnover rates indicate only the same set of species will be able to colonize the habitat, reducing the biological diversity of these systems.

Many investigations have been carried out with Ephemeroptera nymphs in reservoirs, among which should be highlighted those of Samways et al. (1996), Ogbogu (2001), Pardo et al. (1998) and of Goulart and Callisto (2005). However, this is the first study in Brazil relating to the colonization of Ephemeroptera assemblage in artificial substrate embedded along a reservoir gradient. We demonstrated changes in the structure and composition of Ephemeroptera community in the longitudinal gradient of Itaipu Reservoir, with species richness decreasing from riverine to lacustrine zones. Biological variations can reflect the dependency degree of species in relation to the lentic and sometimes-lotic conditions imposed by damming, altering, mainly the natural river flow. Although nymphs of few Ephemeroptera species were able to colonize the artificial substrates, such group can be considered a good environmental indicator. In this way, from the species losses along of spatial gradient, we could infer that can be occurring human-mediated impacts on the Itaipu reservoir, as the currently so-called community homogenization.

\section{Acknowledgements}

We would like to thank the financial support of Itaipu Binacional. Special thanks to all employees and students who helped in sorting and collections and to logistical support of Nupelia / UEM.

\section{References}

AGOSTINHO, A.A., MIRANDA, L.E., BINI, L.M., GOMES, L.C., THOMAZ, S.M. and SUZUKI, H.I., 1999. Patterns of colonization in neotropical reservoirs, and prognoses on aging. In: J.G. TUNDISI, M. STRASKRABA, eds. Theoretical reservoir ecology and its applications. The Netherlands: Backhuys Publishers, pp. 227-265.

BARBER-JAMES, H.M., GATTOLLIAT, J.L., SARTORI, M. and HUBBARD, M.D., 2008. Global diversity of mayflies (Ephemeroptera, Insecta) in freshwater. Hydrobiologia, vol. 595, no. 1, pp. 339-350. http://dx.doi.org/10.1007/s10750-007-9028-y.

BASELGA, A., 2010. Partitioning the turnover and nestedness components of beta diversity. Global Ecology and Biogeography, vol. 19, no. 1, pp. 134-143. http://dx.doi.org/10.1111/j.14668238.2009.00490.x.

BASELGA, A., 2012. The relationship between species replacement, dissimilarity derived from nestedness, and nestedness. Global 
Ecology and Biogeography, vol. 21, no. 12, pp. 1223-1232. http:// dx.doi.org/10.1111/j.1466-8238.2011.00756.x.

BRITTAIN, J.E. and SALTVEIT, S.J., 1989. A review of the effect of river regulation on Mayflies (Ephemeroptera). Regulated Rivers: Researcii \&. Management, vol. 3, pp. 191-204.

CLARKE, K.R., 1993. Non-parametric multivariate analyses of changes in community structure. Australian Journal of Ecology, vol. 18, no. 1, pp. 117-143. http://dx.doi.org/10.1111/j.1442-9993.1993. tb00438.x.

DIAS, L.G. and SALLES, F.F., 2005. Three new species of Tricorythopsis (Ephemeroptera: Leptohyphidae) from southeastern Brazil. Aquatic Insects, vol. 27, no. 4, pp. 235-241. http://dx.doi. org/10.1080/01650420500336657.

DIAS, L.G., 2005. Taxonomia e distribuição de Ephemerolloidea (Insecta Ephemeroptera) na região sudeste do Brasil. Viçosa: Universidade Federal de Viçosa. Dissertação de mestrado.

DOBROVOLSKI, R., MELO, A.S., CASSEMIRO, F.A.S. and DINIZ-FILHO, J.A.F., 2012. Climatic history and dispersal ability explain the relative importance of turnover and nestedness components of beta diversity. Global Ecology and Biogeography, vol. 21, no. 2, pp. 191-197. http://dx.doi.org/10.1111/j.14668238.2011.00671.x.

DOMÍNGUEZ, E., HUBBARD, M.D., PESCADOR, M.L. and MOLINERI, C., 2001. Ephemeroptera. In: H.R. FERNANDES, E. DOMÍNGUEZ, eds. Guia para la determinación de los artrópodos bentónicos sudamericanos. Tucumán: Universidade Nacional de Tucumán, pp. 17-53.

DOMÍNGUEZ, E., MOLINERI, C., PESCADOR, M.L., HUBBARD, M.D. and NIETO, C., 2006. Ephemeroptera of South America. Moscow: Pensoft, pp. 1-646. Aquatic Biodiversity of Latin America, vol. 2.

FATTORINI, S. and BASELGA, A., 2012. Species richness and turnover patterns in European tenebrionid beetles. Insect Conservation and Diversity, vol. 5, no. 5, pp. 331-345. http:// dx.doi.org/10.1111/j.1752-4598.2011.00164.x.

FLORENTINO, A.C. and PENHA, J.M., 2011. High beta diversity of fish in vegetated littoral zones of floodplain lakes in the Cuiabá River Basin, Northern Pantanal, Brazil. Hydrobiologia, vol. 1, no. 1, pp. 137-146. http://dx.doi.org/10.1007/s10750-011-0697-1.

FRANCISCHETTI, C.N., SILVA, E.R., SALLES, F.F. and NESSIMIAN, J., 2004. A Efemeropterofauna (Insecta: Ephemeroptera) do trecho ritral inferior do Rio Campo Belo, Itatiaia, RJ: composição e mesodistribuição. Lundiana, vol. 5, no. 1, pp. 33-39.

GILLER, P.S. and CAMBELL, R.N.B., 1989. Colonisation patterns of mayfly nymphs (Ephemeroptera) on implanted substrate trays of different size. Hydrobiologia, vol. 178, no. 1, pp. 59-71. http:// dx.doi.org/10.1007/BF00006113.

GOULART, M. and CALLISTO, M., 2005. Mayfly distribution along a longitudinal gradient in Serra do Cipó, southeastern Brazil. Acta Limnologica Brasiliensia, vol. 7, no. 1, pp. 1-13.

HORTAL, J., DINIZ-FILHO, J.A.F., BINI, L.M., RODRÍGUEZ, M.Á., BASELGA, A., NOGUÉS-BRAVO, D., RANGEL, T.F., HAWKINS, B.A. and LOBO, J.M., 2011. Ice age climate, evolutionary constraints and diversity patterns of European dung beetles. Ecology Letters, vol. 14, no. 8, pp. 741-748. PMid:21645193. http://dx.doi.org/10.1111/j.1461-0248.2011.01634.x.
HYNES, H.B., 1970. The ecology of stream insects. Annual Review of Entomology, vol. 15, no. 1, pp. 25-41. http://dx.doi. org/10.1146/annurev.en.15.010170.000325.

LEGENDRE, P. and LEGENDRE, P., 1998. Numerical Ecology: developments in environmental modelling. 2nd ed. Amsterdam: Elsevier Science. 970 p.

LEPRIEUR, F., TEDESCO, P.A., HUGUENY, B., BEAUCHARD, O., DÜRR, H.H., BROSSE, S. and OBERDORFF, T., 2011. Partitioning global patterns of freshwater fish beta diversity reveals contrasting signatures of past climate changes. Ecology Letters, vol. 14, no. 4, pp. 325-334. PMid:21303436. http://dx.doi. org/10.1111/j.1461-0248.2011.01589.x.

LUGO-ORTIZ, C.R. and MCCAFFERTY, W.P., 1996. Taxonomy of the Neotropical genus Americabaetis, new status (Insecta: Ephemeroptera: Baetidae). Studies on Neotropical Fauna and Environment. vol. 31, pp. 156-169.

MELO, A.S., SCHNECK, F., HEPP, L.U., SIMÕES, N.R., SIQUEIRA, T. and BINI, L.M., 2011. Focusing on variation: methods and applications of the concept of beta diversity in aquatic ecosystems. Acta Limnologica Brasiliensia, vol. 23, no. 3, pp. 318-331. http://dx.doi.org/10.1590/S2179-975X2012005000010.

MELO, S.M., TAKEDA, A.M. and BÜTTOW, N.C., 1993. Life history of nymphs of Campsurus violaceus Needham and Murphy, 1924 (Ephemeroptera, Polymitarcyidae) in the Baía River (MSBrasil). Revista Unimar, vol. 15, pp. 95-107.

MELO, S.M., TAKEDA, A.M. and MONKOLSKI, A., 2002. Seasonal dynamics of Callibaetis willineri (Ephemeroptera, Baetidae) associated with Eichhornia azurea (Pontedericeae) in Guaraná Lake of the Upper Paraná River, Brazil. Hydrobiologia, vol. 470, no. 1/3, pp. 57-62. http://dx.doi.org/10.1023/A:1015617102463.

MELO, S.M., TAKEDA, A.M. and MONKOLSKI, A., 2004. Distribution of ephemeropteran nymphs associated with different stolon sections of Eichhornia azurea (Schwartz) in two floodplain Lakes of the Upper Paraná River (Brazil). Polish Journal of Ecology, vol. 52, pp. 369-376.

MERRITT, R.W. and CUMMINS, K.W., 1996. An introduction to the aquatic insects of North America. 2nd ed. Iowa: Kendall Hunt. $538 \mathrm{p}$.

MOLINERI, C., 2001. Traverhyphes: a new genus of Leptohyphidae for Leptohyphes indicator and related species (Insecta: Ephemeroptera). Spixiana, vol. 24, pp. 129-140.

MORENO-OSTOS, E., MARCÉ, R., ORDÓÑEZ, J., DOLZ, J. and ARMENGOL, J., 2008. Hydraulic management drives heat budgets and temperature trends in a Mediterranean Reservoir. International Review of Hydrobiology, vol. 93, no. 2, pp. 131147. http://dx.doi.org/10.1002/iroh.200710965.

NELSON, J.S., 1994. Fishes of the world. 3rd ed. New York: Wiley Interscience. $523 \mathrm{p}$

NOLTE, U., TIETBÖHL, R.S. and MCCAFFERTY, W.P., 1996. A mayfly from tropical Brasil capable of tolerating short-term dehydration. Journal of the North American Benthological Society, vol. 15, no. 1, pp. 87-94. http://dx.doi.org/10.2307/1467434.

OGBOGU, S.S., 2001. Factors affecting the distribution and abundance of Cloeon and Caenis (Ephemeroptera) larva in a tropical impounded river, Nigeria. African Journal of Ecology, vol. 39, no. 1, pp. 106-112. http://dx.doi.org/10.1046/j.13652028.2001.00283.x. 
OKADA, E., AGOSTINHO, A.A. and GOMES, L.C., 2005. Spatial and temporal gradients in artisanal fisheries of a large Neotropical reservoir, the Itaipu Reservoir, Brazil. Canadian Journal of Fisheries and Aquatic Sciences, vol. 62, no. 3, pp. 714-724. http://dx.doi.org/10.1139/f05-015.

OLIVEIRA, E.F., MINTE-VERA, C.V. and GOULART, E., 2005. Structure of fish assemblages along spatial gradients in a deep subtropical reservoir (Itaipu Reservoir, Brazil-Paraguay border). Environmental Biology of Fishes, vol. 72, no. 3, pp. 283304. http://dx.doi.org/10.1007/s10641-004-2582-5.

PAGIORO, T.A. and THOMAZ, S.M., 2002. Longitudinal patterns of sedimentation in a deep, monomictic subtropical reservoir (Itaipu, Brazil-Paraguay). Archiv für Hydrobiologie, vol. 154 , no. 3 , pp. 515-528. http://dx.doi.org/10.1127/archivhydrobiol/154/2002/515.

PARDO, I., CAMPBELL, I.C. and BRITTAIN, J.E., 1998. Influence of dam operation on mayfly assemblage structure and life histories in two south-eastern Australian streams. Regulated Rivers: Research and Management, vol. 14, no. 3, pp. 285-295. http:// dx.doi.org/10.1002/(SICI)1099-1646(199805/06)14:3<285::AIDRRR502>3.0.CO;2-6.

QIAN, H., RICKLEFS, R.E. and WHITE, P.S., 2005. Beta diversity of angiosperms in temperate floras of eastern Asia and eastern North America. Ecology Letters, vol. 8, no. 1, pp. 15-22. http://dx.doi.org/10.1111/j.1461-0248.2004.00682.x.

R DEVELOPMENT CORE TEAM, 2014. $R$ : A language and environment for statistical computing. Vienna: R Foundation for Statistical Computing.

SALLES, F.F., SILVA, E.R., HUBBARD, M. and SERRÃO, J.E., 2004. As espécies de Ephemeroptera (Insecta) registradas para o Brasil. Biota Neotropica, vol. 4, pp. 1-34.

SAMWAYS, M.J., OSBORN, R. and VAN HEERDEN, I., 1996. Distribuition of benthic invertebrates at different depths in a shallow reservoir in the Kwazulu-Natal Midlands. Koedoe, vol. 39, no. 2, pp. 69-76. http://dx.doi.org/10.4102/koedoe.v39i2.295.

SHIMANO, Y., SALLES, F.F. and CABETTE, H.S.R., 2011. Ephemeroptera (Insecta) ocorrentes no Leste do Estado do Mato Grosso, Brasil. Biota Neotropica, vol. 11, no. 4, pp. 239-253. http://dx.doi.org/10.1590/S1676-06032011000400021.

SILVA, E.R., 1997. A alimentação de ninfas de Callibaetis guttatus Navás, 1915 (Ephemeroptera, Baetidae) em um brejo temporário do litoral do Estado do Rio de Janeiro. Revista Brasileira de Entomologia, vol. 41, pp. 53-55.

SIMPSON, G.G., 1943. Mammals and the nature of continents. American Journal of Science, vol. 241, no. 1, pp. 1-31. http:// dx.doi.org/10.2475/ajs.241.1.1.

STATSOFT INC, 2005 [viewed 17 June 2017] Statistica (data analysis software system): version 7.1. Available from: www. statsoft.com
SVENNING, J.C., FLØJGAARD, C. and BASELGA, A., 2011. Climate, history and neutrality as drivers of mammal beta diversity in Europe: insights from multiscale deconstruction. Journal of Animal Ecology, vol. 80, no. 2, pp. 393-402. PMid:21070238. http://dx.doi.org/10.1111/j.1365-2656.2010.01771.x.

TABACCHI, E., DÉCAMPS, H. and THOMAS, A., 1993. Substrate interstices as a habitat for larval Thraulus bellus (Ephemeroptera) in a temporary floodplain pond. Freshwater Biology, vol. 29, no. 3, pp. 429-439. http://dx.doi.org/10.1111/j.1365-2427.1993.tb00777.x.

TANIWAKI, R.H., MAGRIN, A.G.E., CALIJURI, M.C. and CARLOS, V.M., 2013. Biomass and elemental composition (C, N, H) of the periphytic community attached to Polygonum punctatum Ell. in a subtropical reservoir and its relationship to environmental factors. Limnetica, vol. 32, no. 2, pp. 189-200.

TERRA, B.F., SANTOS, A.B.I. and ARAÚJO, F.G., 2010. Fish assemblage in a dammed tropical river: an analysis along the longitudinal and temporal gradients from river to reservoir. Neotropical Ichthyology, vol. 8, no. 3, pp. 599-606. http://dx.doi. org/10.1590/S1679-62252010000300004.

THORNTON, K.W., KENNEDY, R.H., CARROL, J.H., WALKER, W.W., GUNKEL, R.C. and ASHBY, S. (1981) Reservoir sedimentation and water quality: an heuristic model. In Proceedings of the Symposioum on Surface Water Impoundments. New York: American Society of Civil Engineers, pp. 654-661.

TONIAL, M.L.S., SILVA, H.L.R., TONIAL, I.J., COSTA, M.C., SILVA JÚNIOR, N.J. and DINIZ-FILHO, J.A.F., 2012. Geographical patterns and partition of turnover and richness components of beta-diversity in faunas from Tocantins river valley. Brazilian Journal of Biology $=$ Revista Brasileira de Biologia, vol. 72, no. 3, pp. 497-504. PMid:22990820. http:// dx.doi.org/10.1590/S1519-69842012000300012.

TUNDISI, J.G., 1996. Reservoir as complex systems. Journal of the Brazilian fur the Advancement of Science, vol. 48, pp. 383-387.

TUOMISTO, H., 2010. A diversity of beta diversities: straightening up a concept gone awry. Part 1. Defining beta diversity as a function of alpha and gamma diversity. Ecography, vol. 33, no. 1, pp. 2-22. http://dx.doi.org/10.1111/j.1600-0587.2009.05880.x.

VELHO, L., LANSAC-TOHA, F., BONECKER, C., BINI, L.M. and ROSSA, D., 2001. The longitudinal distribution of copepods in Corumbá Reservoir, State of Goiás, Brazil. Hydrobiologia, vol. 453, pp. 385-391. http://dx.doi.org/10.1023/A:1013194118104.

WETZEL, R.G., 1990. Reservoir ecosystems: conclusions and speculations. In: K.W. THORNTON, B.L. KIMMEL and F.E. PAYNE, eds. Reservoir Limnology: ecological perspectives. New York: Wiley Interscience, pp. 227-238.

ZELINKA, M., 1984. The effects of low discharge rates on mayfly fauna. In: Proceedings of the 4th International Conference on Ephemeroptera. Czech: Institute of Entomology, pp. 323-328. 